Para citar este artículo: Gomes Batista, M. D., \& Barbosa Felix, V. (2019). O uso de grupos do WhatsApp por comunidades de jogo: impulsionando a comunicação e estreitando laços sociais. Anuario Electrónico de Estudios en Comunicación Social "Disertaciones", 12(1), 88-111. Dol: http://dx.doi.org/10.12804/revistas. urosario.edu.co/disertaciones/a.6074

\title{
O USO DE GRUPOS DO WHATSAPP POR COMUNIDADES DE JOGO: IMPULSIONANDO A COMUNICAÇÃO E ESTREITANDO LAÇOS SOCIAIS
}

The Use of WhatsApp Groups by Communities of Play: Promoting the Communication and Strengthening Social Ties

El uso de grupos de WhatsApp por comunidades de juego: impulsando la comunicación y estrechando lazos sociales

Micheline Dayse Gomes Batista, Universidade Federal de Pernambuco (UFPE), Brasil micheline.batista@gmail.com

Vilma Barbosa Felix, Universidade Federal de Pernambuco (UFPE), Brasil vilmafelix@hotmail.com

Recebido: 15 de setembro de 2017

Aprobado: 13 de março de 2018

\section{RESUMO}

Este trabalho tem como objetivo analisar as possibilidades comunicacionais e de sociabilização em comunidades de jogos digitais, que incluem desde chat rooms no ambiente do próprio jogo a grupos em aplicativos de mensagens instantâneas como o WhatsApp. Partimos de um relato etnográfico no jogo Elves vs. Dwarves para demonstrar 
que os grupos do WhatsApp permitem levar a experiência do jogo para além do próprio jogo, estendendo-se às práticas cotidianas dos jogadores.

Palavras-chave: jogos digitais, comunicação móvel, sociabilidade.

\section{ABSTRACT}

This paper aims to analyze communication and socialization possibilities in digital game communities, ranging from chat rooms in the game environment to groups in instant messaging applications such as WhatsApp. We begin with an ethnographic account in the game Elves vs. Dwarves to demonstrate that WhatsApp groups allow you to take the game experience beyond your own game, extending to the player's daily practices.

Keywords: Digital games, mobile communication, sociability.

\section{RESUMEN}

Este trabajo tiene como objetivo analizar las posibilidades comunicacionales y de sociabilización en comunidades de juegos digitales, que incluyen desde chat rooms en el ambiente del propio juego a grupos en aplicativos de mensajes instantáneos como el WhatsApp. Partimos de un relato etnográfico en el juego Elves vs. Dwarves para demostrar que los grupos de WhatsApp permiten llevar la experiencia del juego más allá del propio juego, ampliando las prácticas cotidianas de los jugadores.

Palabras clave: juegos digitales, comunicación móvil, sociabilidad.

\section{Introdução}

Games de estratégia aparentemente simples, gratuitos e exclusivos para serem jogados online em dispositivos móveis podem nos oferecer importantes insights sobre as possibilidades comunicacionais e de sociabilização em comunidades de jogo, inclusive possibilidades que vão além do próprio jogo. Um game como Elves vs. Dwarves (EvD), por exemplo, disponibiliza, no próprio aplicativo, salas de bate-papo em tempo real para conversas em ambiente aberto, ao qual todos os jogadores têm acesso ( $\mathrm{global}$ chat); conversas entre membros da mesma aliança; conversas entre os oficiais; e conversas privadas entre dois jogadores (chamadas 'cochichos'). Além das chat rooms, nas quais cada mensagem pode ter até 140 caracteres, o jogo também oferece um correio por meio do qual os jogadores podem trocar mensagens de forma assíncrona. 


\section{DISERTACIONES}

ESTUDIOS

Comunicación y dispositivos móviles

ISSN: 1856-9536

Dol de la revista: http://dx.doi.org/10.12804/disertaciones

Volumen 12, Número 1 / Enero-junio 2019

Versión PDF para imprimir desde

http://revistas.urosario.edu.co/index.php/disertaciones

O curioso é que, a despeito dessas várias possibilidades comunicacionais, comuns a muitos jogos digitais, tem sido cada vez mais frequente a utilização de aplicativos de mensagens instantâneas para celulares, em especial o WhatsApp, para conectar membros de comunidades de jogo. Uma das razões para este fenômeno parece ser a oferta de recursos que o ambiente dos jogos não é capaz de oferecer, como a opção de enviar e receber mensagens de áudio, fotos e vídeos. Outra vantagem é a capacidade de manter os jogadores conectados e interagindo mesmo quando não estão no ambiente do game.

Ao ingressar em um ou mais grupos de sua aliança no WhatsApp, os jogadores de EvD podem trocar informações sobre o jogo em si, principalmente sobre torneios em curso, e dicas em geral sobre como evoluir cidades e heróis mais rapidamente. Evidentemente, as conversas não se limitam aos temas relacionados ao jogo e acabam versando sobre assuntos diversos, ligados ao cotidiano das pessoas, principalmente porque o aplicativo acrescenta um elemento de realidade a um jogo que, por definição, está baseado na virtualidade. No WhatsApp, o jogador passa a publicizar dados pessoais que até então limitavam-se ao seu nickname no jogo, tais como nome, telefone (e consequentemente cidade e país onde reside), foto e outras informações que constem em seu perfil.

Como o EvD é dividido em mundos, também tem sido comum a criação de grupos do WhatsApp para reunir regentes de alianças pertencentes a um mundo (ou servidor) específico e ainda grupos para conectar regentes ao mediador responsável pelo(s) mundo(s) em que jogam. Na maioria dos casos, o mediador é um jogador fluente em inglês que leva as demandas dos jogadores aos desenvolvedores do jogo e vice-versa. Todos esses grupos podem ser considerados comunidades de jogo, porém nosso foco neste trabalho são aqueles que reúnem membros de uma mesma aliança e suas interações, tanto no ambiente do próprio game quanto no aplicativo de mensagens instantâneas.

Com esse foco definido, pretendemos analisar o aspecto relacional presente nos jogos digitais que é potencializado pelos aplicativos de mensagens instantâneas para celulares. Boa parte da literatura existente sobre jogos digitais concentra-se no aspecto estrutural desses artefatos (importância cultural e econômica, funcionamento, recursos inovadores) ou na experiência imersiva que eles podem proporcionar aos jogadores individualmente (aspectos psicológicos). Nosso intuito é contribuir, ainda que preliminarmente, para a ampliação dos estudos de games multijogadores enquanto veículos interativos capazes de formar e manter comunidades para além das fronteiras do próprio game.

Para tanto, pretendemos apresentar um breve cenário teórico em que abordamos o tema comunidades de jogo como um fenômeno cultural, incluindo alguns números da indústria de games e perfil dos jogadores. Partimos de um conceito mais amplo de jogo utilizado por Huizinga (2007), sua ideia de "círculo mágico" e o rompimento desse círculo, isto é, sua "contaminação" com aspectos da vida corrente ou vice-versa, como verificamos que ocorre com os grupos que abrigam comunidades de jogo no aplicativo WhatsApp.

Na sequência, apresentamos uma caracterização do nosso objeto empírico, no caso, o game EvD. O que é, como e quando surgiu, suas peculiaridades, estrutura, narrativa, personagens, recursos oferecidos e como ocorre o desenvolvimento dos jogadores e das alianças. Damos uma atenção especial à dinâmica que envolve a formação e o funcionamento das alianças em EvD - tipos de alianças, estruturas, hierarquias e benefícios que propiciam aos membros-.

Em seguida, tecemos algumas considerações metodológicas sobre a abordagem escolhida para tratar a parte empírica deste trabalho, que consiste em um relato etnográfico baseado em memórias, das impressões de uma jogadora 


\section{DISERTACIONES}

ESTUDIOS

Comunicación y dispositivos móviles

ISSN: 1856-9536

Dol de la revista: http://dx.doi.org/10.12804/disertaciones

Volumen 12, Número 1 / Enero-junio 2019

Versión PDF para imprimir desde

http://revistas.urosario.edu.co/index.php/disertaciones

pertencente a uma das alianças de $E v D$, a Gods of War. O próximo passo será apresentar esse relato, feito na primeira pessoa, uma vez que a jogadora é também autora deste artigo. Por fim, apresentamos as considerações finais.

\section{Comunidades de jogo como um fenômeno cultural}

Em outro trabalho (Batista, 2010) já havíamos notado que o interesse acadêmico por jogos digitais é recente. Pode-se afirmar que coincide com a expansão dessa indústria, a partir dos anos 2000, despertando a atenção de estudiosos de áreas como educação, sociologia, antropologia, comunicação e psicologia. Sem embargo, tais artefatos, especialmente os multijogadores, têm adquirido grande importância cultural e econômica. De acordo com Aarseth (2001), os games combinam aspectos estéticos e sociais de uma forma que a "velha mídia" (teatro, TV, cinema, literatura) jamais conseguiu. Vale destacar alguns números dessa indústria. Em 2016, jogos de computador e videogames movimentaram US\$30,4 bilhões, incluindo as vendas de conteúdos, hardwares e acessórios, segundo dados da Entertainment Software Association (ESA) (2017). Esta cifra se aproxima, por exemplo, do que faturou o cinema no mesmo ano: US\$38,6 bilhões (uol Cinema, 2017).

Temos acompanhado, também, uma mudança gradual no perfil dos jogadores. A ideia de que game é coisa de indivíduos jovens do sexo masculino vai ficando cada vez mais distante. O levantamento da ESA (2017) mostra que a idade média dos gamers é 35 anos e que $41 \%$ dos jogadores são mulheres. Outro aspecto interessante é que $54 \%$ dos jogadores afirmam que jogos de computador e videogames ajudam a conectá-los com amigos. No Brasil, o público feminino está em contínuo crescimento, como atesta a pesquisa da Sioux, Blend New Research e ESPM (2017). A maioria dos gamers brasileiros tem de 25 a 34 anos, sendo que 77,9\% deles jogam em plataforma mobile.

A ideia de jogo como fenômeno cultural está intimamente relacionada à ideia de cultura em sentido mais amplo: cultura enquanto compartilhamento, seja de uma linguagem, de rituais, de uma mitologia própria, valores ou de simples práticas diárias. Pearce (2011, p. 51) nos lembra que tais práticas são, fundamentalmente, intersubjetivas, isto é, construídas por meio das interações entre as pessoas. Aí reside a função social do jogo.

Mas, mais do que o compartilhamento de significados, jogos digitais possibilitam a comunicação direta entre os jogadores, estimulando o desenvolvimento de redes e habilidades sociais. É justamente este aspecto relacional -a sociabilidade possibilitada por jogos digitais - que mais nos interessa aqui. No entanto, para alcançarmos uma compreensão mais ampla dessa questão, faz-se necessário conceituarmos antes o que é o jogo e o que são as comunidades de jogo.

Aqui adotamos um conceito mais amplo de jogo, aquele que remete à expressão ludus, que vem do latim, utilizado por Huizinga (2007), que afirma se tratar de um fenômeno mais antigo do que a própria cultura. "Ludus abrange os jogos infantis, a recreação, as competições, as representações litúrgicas e teatrais e o os jogos de azar" (Huizinga, 2007, p. 41). Nascemos homo ludens, isto é, convivemos com o elemento lúdico desde pequenos, seja através das brincadeiras livres, com bonecas ou carrinhos. Quando as brincadeiras ficam mais 'sérias' e ganham regras, tornam-se jogos, embora essa noção não precise necessariamente estar atrelada a uma competição ou disputa por alguma coisa. $\mathrm{O}$ autor define o jogo como

uma atividade livre, conscientemente tomada como "não-séria" e exterior à vida habitual, mas ao mesmo tempo capaz de absorver o jogador de maneira intensa e total. É uma atividade desligada de todo e qualquer interesse material, com a qual não se pode obter qualquer lucro, praticada dentro de limites espaciais 


\section{DISERTACIONES}

ESTUDIOS

Comunicación y dispositivos móviles

ISSN: 1856-9536

Dol de la revista: http://dx.doi.org/10.12804/disertaciones

Volumen 12, Número 1 / Enero-junio 2019

Versión PDF para imprimir desde

http://revistas.urosario.edu.co/index.php/disertaciones

e temporais próprios, segundo uma certa ordem e certas regras. Promove a formação de grupos sociais com tendência a rodearem-se de segredo e a sublinharem sua diferença em relação ao resto do mundo por meio de disfarces ou outros meios semelhantes (Huizinga, 2007, p. 16).

Significa que o jogo é uma atividade voluntária e que encerra um determinado sentido que está além das necessidades imediatas da vida. Possui uma intensidade e um poder de fascinação cuja essência é o divertimento. Sua realidade é autônoma, pois se realiza em "uma esfera temporária de atividade com orientação própria” (Huizinga, 2007, p. 11). O espaço do jogo é previamente delimitado, seja material ou imaginariamente, constituindo-se um campo "sagrado", isolado e com regras próprias. O jogo se inicia e só acaba quando chega a um certo "fim". Porém, enquanto dura, reveste-se de tensão, equilíbrio, variação, união e desunião. A tensão advém do acaso, por não sabermos como o jogo terminará.

O tal círculo mágico do jogo, segundo Huizinga (2007, pp. 11-12), aproxima-se da noção que temos de grandes atividades arquetípicas da sociedade humana, como a linguagem (por meio das metáforas, que nada mais são do que jogos de palavras) e o mito (que usa a imaginação na interpretação de fenômenos do mundo exterior). Assim também como o culto e o ritual, o jogo nos proporciona uma "evasão da vida 'real", um "intervalo em nossa vida quotidiana" capaz de nos absorver inteiramente.

O que ocorre após esse "intervalo"? É possível encerrar o sentido da ação depois de acabado o jogo ou algo daquela situação excepcional consegue sobreviver após retornarmos às nossas vidas cotidianas? A resposta é: sim. Esse algo sobrevive por meio das comunidades de jogo, pois "As comunidades de jogadores geralmente tendem a tornar-se permanentes, mesmo depois de acabado o jogo" (Huizinga, 2007, p. 15). As sociedades lúdicas se mantêm a partir da magia que é conservada para além da duração de cada jogo, a magia de estarmos "separadamente juntos", partilhando algo importante que está apartado do resto do mundo e de suas normas habituais.

Huizinga (2007, p. 15) admite que nem todos os jogos levam à fundação de um clube, mas, quando isso ocorre, fica difícil separar o domínio lúdico dos agrupamentos sociais permanentes, especialmente nas culturas arcaicas, em que costumes e rituais são sobrevalorizados. Mas, se a magia do jogo é capaz de sobreviver ao fim da partida e de mobilizar um grupo de pessoas em torno desse universo, talvez o tal "círculo mágico" não tenha fronteiras assim tão definidas e impenetráveis, podendo ser imaginado como uma membrana, algo poroso, que deixa escapar elementos da vida "real" para o virtual e vice-versa, como observa Pearce (2011, pp. 25-26).

Para outro autor clássico da literatura dos jogos, Caillois (1990), o rompimento do círculo sagrado do jogo, ou seja, seu lugar e tempo ausentes da realidade, pode significar o fim do próprio jogo, em seus termos, a corrupção do jogo. Segundo sua abordagem, a contaminação da vida corrente na esfera do jogo ameaça corromper sua própria natureza, transgredindo códigos, regras e convenções aceitas no momento em que se entra no jogo. Tal rompimento poderia levar ao exagero dos instintos, que o jogo teria a função de satisfazer de maneira ideal e circunscrita, e que fora do mundo regulado do jogo subordinariam a vida corrente às necessidades mais específicas de cada um deles. Caillois (1990, p. 77) concebe, por exemplo, o Alea, representado por jogos de loterias ou cassinos, cuja integração na vida social poderia ser percebida em especulações da bolsa de valores e a corrupção do jogo poderia levar à superstição, astrologia etc., tornando-se uma ideia fixa, obsessão e fonte de angústias.

A preocupação de Caillois com a corrupção do jogo, através do contágio com a vida real, sugere, ao contrário de Pearce, um certo radicalismo ou limitação em seu conceito inicial de jogos. Este fato demonstra, desde o princípio, uma tensão estabelecida entre perceber o jogo como algo à parte da vida cotidiana e sua função social de 


\section{DISERTACIONES}

ESTUDIOS

Comunicación y dispositivos móviles

ISSN: 1856-9536

Dol de la revista: http://dx.doi.org/10.12804/disertaciones

Volumen 12, Número 1 / Enero-junio 2019

Versión PDF para imprimir desde

http://revistas.urosario.edu.co/index.php/disertaciones

intersubjetividade e interação que, não necessariamente, conseguimos colocar entre parênteses quando mudamos de ambiente. Podendo indicar, talvez, que tal concepção não seja mais suficiente para contemplar as mais diversas experiências possibilitadas, sobretudo, em jogos digitais online.

As características do jogo, que fundamentam sua definição como uma atividade livre, delimitada, incerta, improdutiva, regulamentada e imaginária, explicitando que as duas últimas características se excluem mutuamente (Caillois, p. 65), indicam também uma outra impossibilidade, desta vez contestada por Juul (2011), que é a coexistência de regras e o "faz de conta" no mundo sagrado do jogo. Para Juul (2011, pp. 12-13), a ficção pode perfeitamente conviver com as regras. As duas coisas não são excludentes e isso foi ficando mais claro a partir dos modernos jogos de tabuleiro e dos videogames, uma vez que os games tradicionais, não digitais, são mais abstratos. Embora a negação da ficção seja sedutora, devemos fugir dessas dicotomias se quisermos apreender a essência do jogo enquanto divertimento.

Videogames são reais na medida em que consistem de regras reais com as quais os jogadores de fato inte-

ragem e na medida em que ganhar ou perder um jogo é um evento real. Entretanto, quando ganhamos um

jogo matando um dragão, o dragão não é um dragão real, mas fictício. Jogar um videogame é, portanto,

interagir com regras reais enquanto imaginamos um mundo fictício, e um videogame é um conjunto de

regras e também um mundo fictício (Juul, 2011, p. 1).

É importante ressaltar que as comunidades de jogo não são um fenômeno recente nem dizem respeito apenas à internet ou a games digitais online. Pearce $(2011$, p. 3) ressalta que este fenômeno já estava presente, por exemplo, nos clubes de xadrez e bridge, nas ligas esportivas de diversos tipos ou, ainda, nos Role-Playing Games (RPG) jogados em tabuleiro. Quando falamos em práticas como Mardi Gras e Halloween, ou mesmo o cosplay, nas quais os adultos costumam vestir fantasias e interpretar papéis, também estamos falando de comunidades de jogo, ainda que de curta duração.

Para chegar ao conceito de comunidade de jogo, Pearce (2011) parte da definição de comunidade (Gemeinschaft) apresentada por Ferdinand Tönnies: uma associação de indivíduos com um objetivo comum, caracterizada pela afiliação a uma identidade de grupo. Importante acrescentar que essa identidade de grupo, para Tönnies (2001), está baseada no entendimento tácito (possibilitado pela linguagem), e no costume, entre outros elementos, indicando um sentido de pertencimento e compromisso mútuo.

Pearce (2011, p. 5) adota o termo "comunidades de jogo" como um contraponto ao termo "comunidades de práticas", que vem da antropologia e se refere a grupos de indivíduos engajados em processos de aprendizagem coletiva e que mantêm uma identidade de grupo definida pelo compartilhamento de interesses ou atividades. Sendo o jogo um tipo de prática, a autora defende a adoção do termo "comunidades de jogo" porque isso garantiria um entendimento próprio de como essas comunidades se formam e são mantidas, isto é, a partir e ao redor de um game.

Assim, tomando as ideias de Huizinga e Pearce como ponto de partida, podemos definir comunidade de jogo como um grupo de pessoas que se reúnem a partir do interesse em um jogo. Esses indivíduos compartilham uma identidade que está relacionada ao game em si e aos interesses que ele desperta como atividade significante. Este grupo não se desfaz quando terminado o momento do jogo, pelo contrário, ele sobrevive para além do próprio jogo, através da troca contínua de informações e experiências relacionadas ao universo do game. 


\section{DISERTACIONES}

ESTUDIOS

Em sua obra, Pearce (2011) nos apresenta um relato de sua experiência em uma comunidade de jogo, a Uru Diaspora, formada por jogadores de um jogo (Uru) que se tornaram refugiados após sua extinção. Sem essa identidade de grupo, possivelmente a comunidade teria se desfeito após a extinção do game. Mas não foi o que aconteceu. 0 que surgiu a partir do Uru sobreviveu ao seu fim, isto é, ao fim do território imaginário que dava significado às práticas cotidianas do grupo. Consideramos tal relato interessante porque nos mostra que a experiência do jogo pode ir além dele mesmo, da mesma forma que entendemos que a criação e manutenção de grupos no WhatsApp por comunidades de jogo podem fomentar o surgimento de agrupamentos sociais permanentes.

\section{Elves vs. Dwarves}

O game EvD foi lançado em junho de 2017 pela chinesa Gaea Technologies em substituição a The Hobbit - Kingdoms of Middle-earth (ком). A substituição ocorreu em função do término da parceria com a Warner Bros., dona da franquia cinematográfica The Hobbit e detentora dos direitos autorais. Com isso, a empresa precisou abandonar todos os elementos que, no game, faziam referência direta ao universo da saga, como nomes, imagens dos personagens, objetos etc. Foi criado, assim, um aplicativo espelho para o qual foram migrados todos os dados de cada usuário. Ou seja, foi criado um aplicativo com a mesma mecânica e funcionalidades de The Hobbit - kom, porém com uma aparência totalmente diferente, sem qualquer alusão aos filmes da franquia, embora a temática envolvendo uma guerra entre elfos e anões tenha sido mantida. Assim, o universo do jogo, que era a Terra-média (Middle-earth), virou Middilgard; a moeda do game, que era mithril, virou mirlith; os heróis Bilbo, Gandalf, Elrond e Thorin viraram Sajok, Enevald, Piffik e Turfan, respectivamente. Já o poderoso dragão Smaug foi renomeado como Fafnir; e assim por diante.

Originalmente, The Hobbit - ком (figura 1) foi lançado em março de 2012 pela desenvolvedora canadense Kabam, em parceria com a Warner Bros (Warner Bros., 2012). 0 jogo, do tipo massively multiplayer online game (ммо), ${ }^{1}$ foi um sucesso desde o início, atraindo milhares de usuários. Inicialmente eram mais de 200 servidores diferentes, divididos por idiomas: inglês, espanhol, turco, russo, francês, alemão, português, italiano, chinês, coreano e japonês. Ao longo do tempo, alguns desses servidores sofreram fusões, a exemplo do Fili10, o Utumno20 e o Vastriel37, todos de língua portuguesa, que foram reunidos no Gloin208.

Em fevereiro de 2017, quando foi anunciada a aquisição dos mobile games da Kabam pela Gaea, entre eles The Hobbit - ком (Gaea, 2017), a empresa chinesa herdou mais de 20 milhões de jogadores (Sensor Tower, 2017), nas plataformas Android e iOS. Observa-se, contudo, que muitos que baixaram o aplicativo e criaram uma conta nos primeiros anos do game não jogam mais, além do que a mudança de The Hobbit - ком para EvD (figura 2) acabou provocando muitas desistências, o que nos leva a crer que há, nesse universo, centenas ou milhares de contas inativas. Sabe-se que algumas pessoas não conseguiram baixar o novo aplicativo, outros esqueceram suas senhas ou simplesmente se recusaram a migrar. Alguns porque não gostaram dos novos gráficos; outros ficaram indignados com a eliminação dos elementos originais que faziam referência à obra de J. R. R. Tolkien e simplesmente abandonaram o game, como atestam algumas críticas publicadas na internet (ver, por exemplo, as reviews contidas no Sensor Tower tanto para The Hobbit - ком quanto para EvD).

1 Os mmos são jogos digitais capazes de suportar um grande número de jogadores jogando simultaneamente por meio da internet. 


\section{DISERTACIONES}

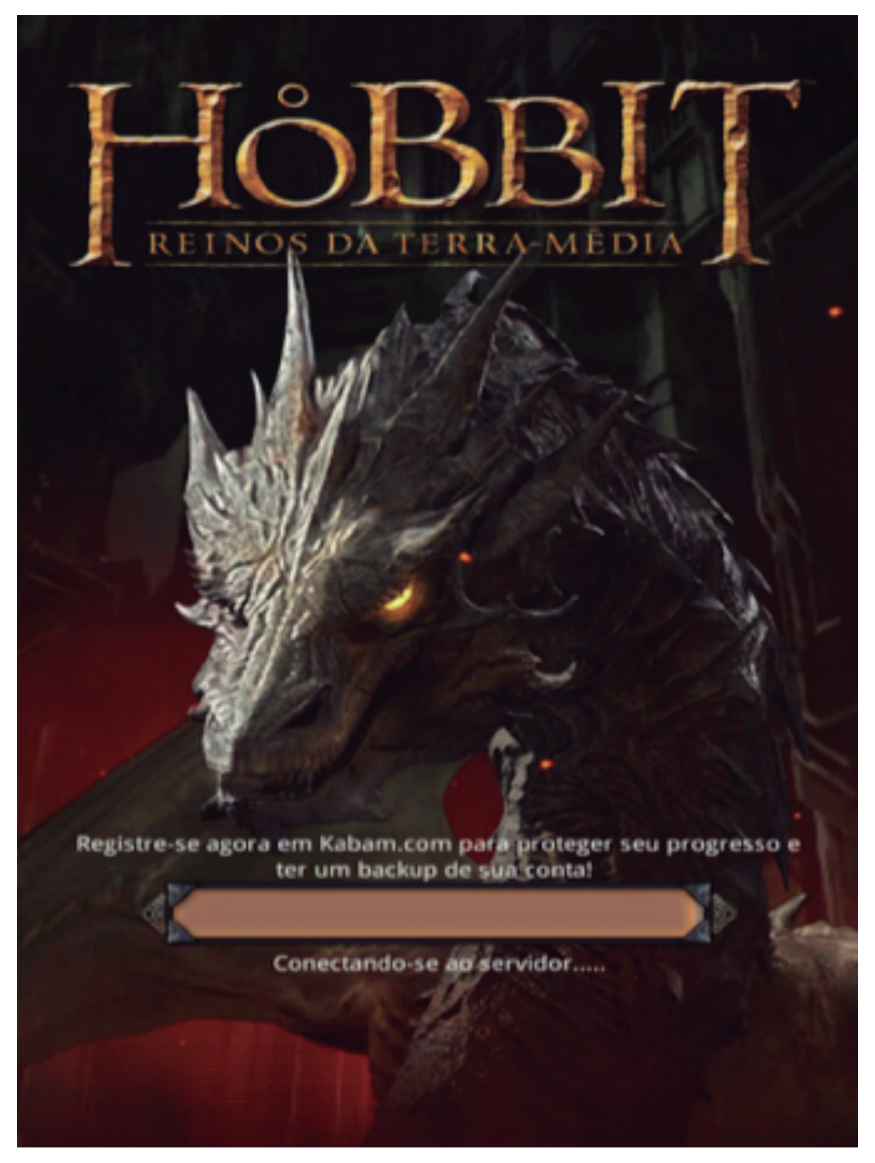

Figura 1. Tela inicial de The Hobbit - ком 


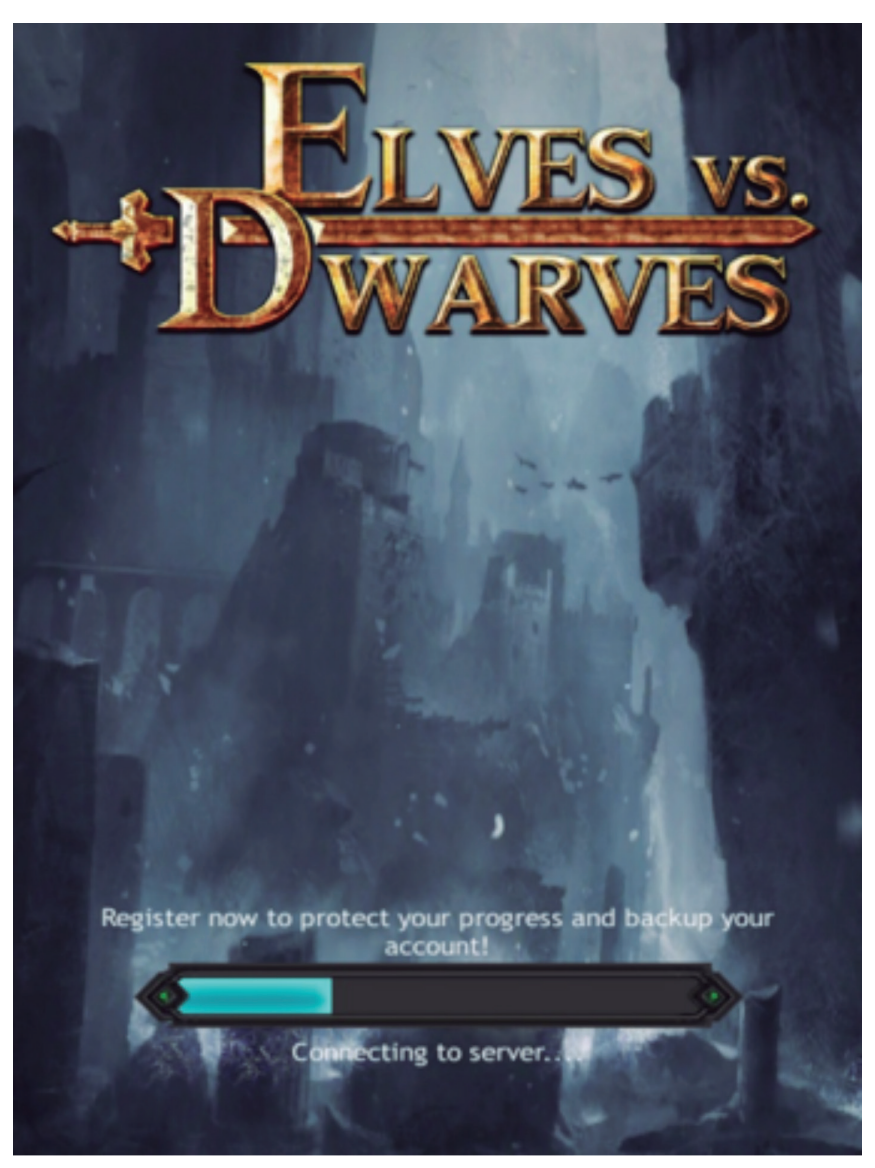

Figura 2. Tela inicial de EvD

Dissemos que EvD é um jogo de estratégia 'aparentemente simples' porque não oferece os recursos realísticos de um massively multiplayer online role-playing game (MMORPG), isto é, não é um mundo virtual dinâmico no qual o jogador é representado por um avatar e interage com outros avatares na tela, a exemplo de títulos como EverQuest, Ragnarök ou World of Warcraft. Trata-se de um ммо com recursos imersivos mais limitados, até porque é exclusivo para plataformas móveis. Enquanto game, sua atratividade reside na possibilidade de, por meio de um celular ou tablet, construir um reino, evoluir os heróis e treinar exércitos para lutar contra goblins e contra outros jogadores.

Ao entrar em EvD, o jogador precisa escolher uma raça - anão ou elfo- e isso vai definir o visual do seu reino e os heróis que nele habitam (figuras 3 e 4). Um tutorial básico ensina os primeiros passos na primeira cidade: construir uma casa, usar runas para acelerar a construção, pesquisar na academia e expandir os campos de recursos (comida, madeira, pedra e metal). É possível construir até cinco cidades - quatro idênticas e a quinta é a chamada de Cidade do Lago-. Além das cidades é preciso evoluir os heróis e buscar equipamentos (arma, capa, colar, escudo e anel) e outros itens, como pedras preciosas, para obter os melhores resultados nas batalhas.

O game é gratuito, mas permite a compra de moeda virtual (mirlith) para aquisição de itens, possibilitando que o jogador fique 'mais forte' em menos tempo. Ainda dentro da economia do jogo, existem algumas ferramentas 


\section{DISERTACIONES}

ESTUDIOS

Comunicación y dispositivos móviles

ISSN: $1856-9536$

Dol de la revista: http://dx.doi.org/10.12804/disertaciones

Volumen 12, Número 1 / Enero-junio 2019

Versión PDF para imprimir desde

externas (ofertadas por terceiros) que podem ser adquiridas, como um GPS (The Hobbit Maps), ${ }^{2}$ que dá a localização, histórico e movimentação de todos os jogadores e alianças em todos os servidores do game; e um sistema (Campaign Score Calculator) ${ }^{3}$ que calcula exatamente que tipos e quantidades de tropas devem ser enviadas para se obter as melhores pontuações nas campanhas.

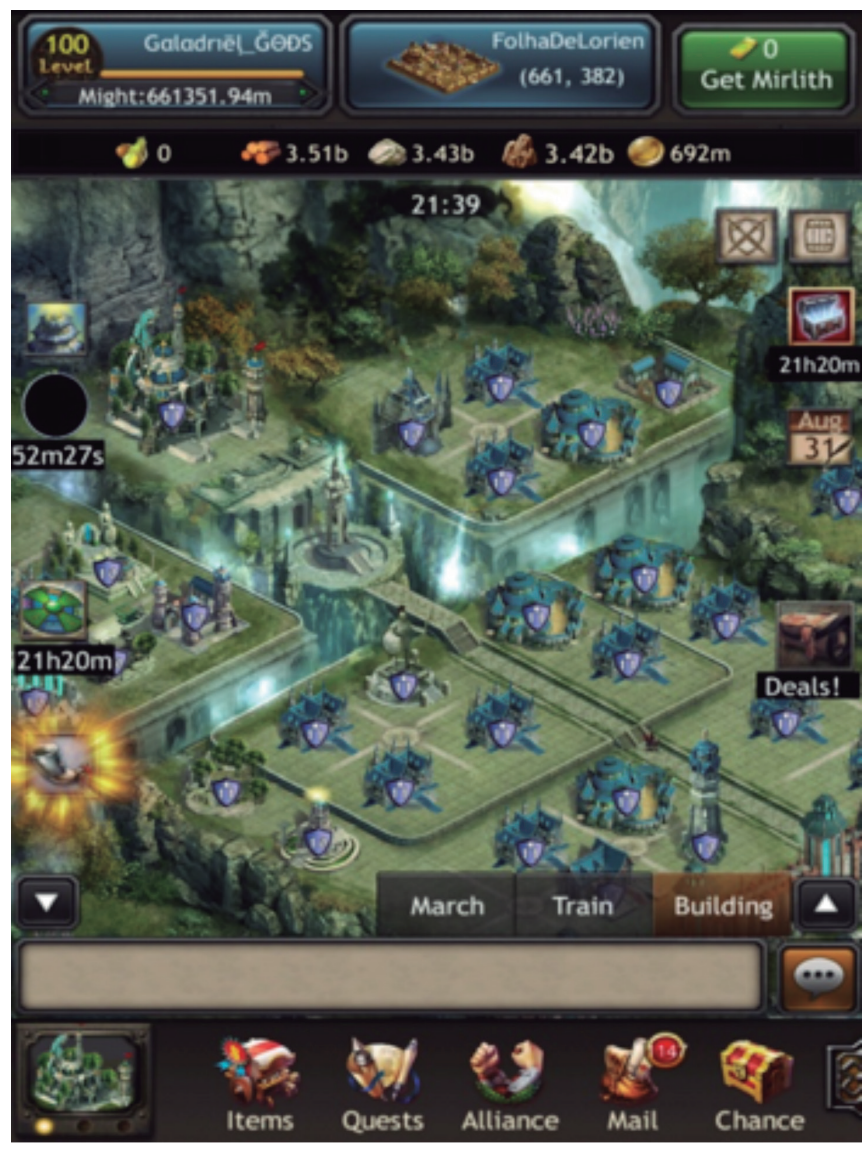

Figura 3. Cidade da raça élfica em EvD

2 https://hobbit.weezeewig.com

3 https://kom-chs.mhweb.in 


\section{DISERTACIONES}

ESTUDIOS

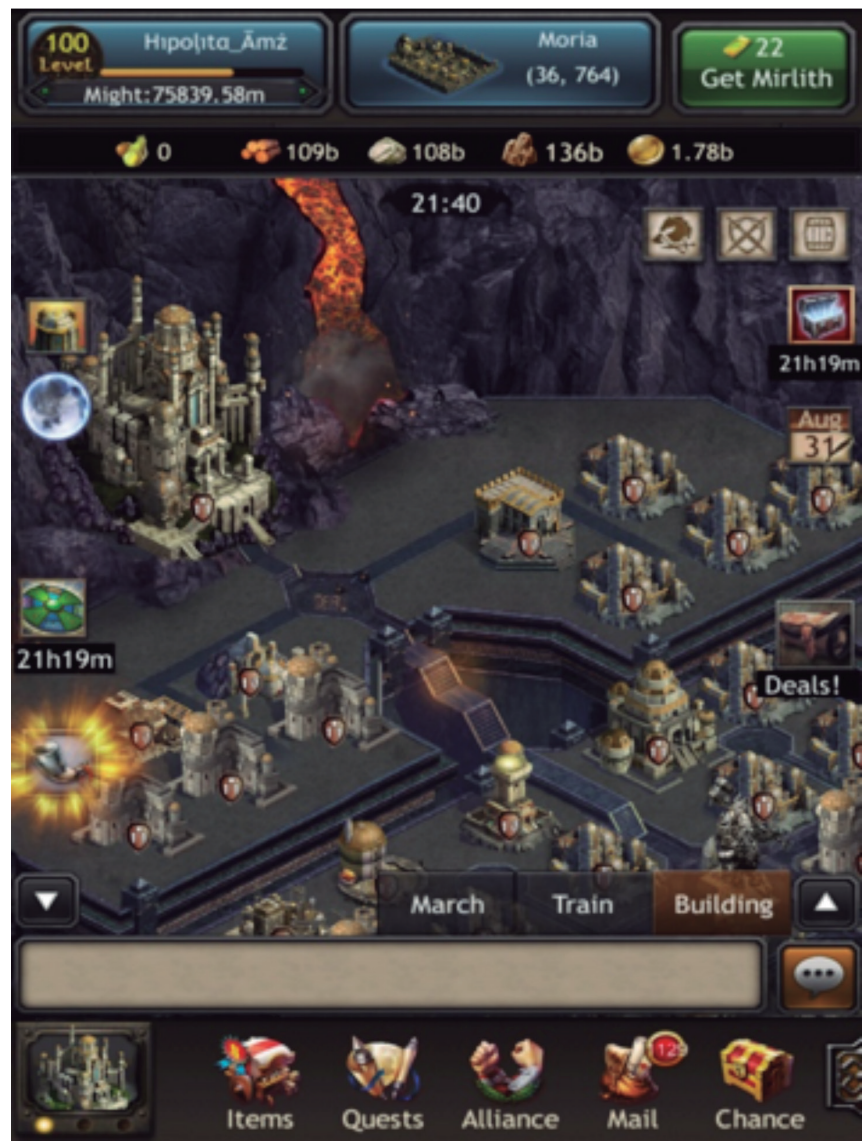

Figura 4. Cidade da raça anã em EvD

Apesar de simples, o game apresenta uma extraordinária riqueza de detalhes. O nível do jogador de EvD vai de 1 a 100, sendo que muitos chegam ao nível máximo sem saber utilizar apropriadamente todos os recursos de jogabilidade, como as runas de batalha permanentes e temporárias, os bônus do guardião da cidade e de tropas, as habilidades certas para cada tipo de herói, o uso das pedras preciosas, incremento e aprimoramento de equipamentos, as montarias, como participar e obter bons resultados em cada tipo torneio (de treino, de força, de matar goblins e chefes goblins, de matar tropas de outros jogadores, campanhas etc.). É neste ponto que as alianças tornam-se fundamentais. Mais do que um somatório de forças ("juntos somos mais fortes" é uma frase de efeito comum entre jogadores de uma mesma aliança), o acesso a recursos e a possibilidade de ganhar prêmios que dificilmente seriam conquistados individualmente, a aliança representa a chance de transmitir e receber informações valiosas sobre o game. O compartilhamento de conhecimentos que normalmente ocorre entre os membros de uma aliança pode fazer com que o jogador evolua mais rapidamente suas cidades e heróis e, assim, avancar como um todo. Dificilmente um jogador obteria uma evolução completa sem pertencer a uma aliança. 


\section{DISERTACIONES}

ESTUDIOS

\section{"Juntos somos mais fortes"}

As alianças em EvD podem abrigar até 100 participantes e funcionam sob o comando de um regente e até dois vice-regentes. Abaixo deles estão os oficiais, o Primeiro Senhor da Guerra e o Segundo Senhor da Guerra. Depois destes vêm os membros comuns. Há tarefas que apenas o regente pode desempenhar, como renomear a aliança, editar sua descrição e os requisitos necessários para admissão de novatos, promover ou rebaixar jogadores. Os vice-regentes podem admitir e excluir aliados, ativar o bônus de treino temporário, entre outras atividades. Já aos oficiais cabe ajudar nos torneios e auxiliar no desenvolvimento dos jogadores menos experientes. Deles costuma-se cobrar, sobretudo, lealdade, assiduidade e participação. Esse grupo formado pelo regente, vice-regentes e oficiais é chamado informalmente de staff. A aliança em si pode evoluir do nível 1 ao 50 e essa evolução depende fundamentalmente da doação diária de recursos e da confiança de Pedras Âmbar de Vala e Pedras Topázio de Vala por parte dos membros. As doações têm um limite diário e através delas os jogadores obtêm Pontos de Honra, que podem ser trocados por itens na Loja da Aliança, tais como recursos, runas e equipamentos.

Embora EvD não seja um MMORPG, pode-se dizer que a estrutura das alianças se assemelha à estrutura das guiIdas (ou clãs) presentes nesse tipo de game. Taylor (2006, pp. 41-42) afirma que essas associações de jogadores tanto tornam o tempo gasto no game mais agradável quanto facilitam o jogar, permitindo ao jogador crescer mais rapidamente e com sucesso, ao mesmo tempo em que faz amizades e participa ativamente da vida social do jogo por meio do canal de bate-papo.

Quando jogadores entram em um grupo eles também têm acesso a um canal de bate-papo para comunicação. Os jogadores usam esse canal não apenas para coordenar sua luta, mas também para pequenas conversas, brincadeiras e conversação em geral. Enquanto a funcionalidade do grupo é mais restrita para facilitar a caça ou a busca colaborativa, ele também se torna um dos métodos primários através do qual os jogadores chegam a fazer novas amizades, aprendem sobre o jogo, criam e aprendem estratégias e, em geral, participam da vida social do jogo (Taylor, 2006, p. 42).

De acordo com a autora, que trata dos MMORPGS em geral e mais especificamente do EverQuest, existem dois tipos de guildas: as guildas familiares (às vezes chamadas de 'guildas sociais'), cuja ênfase reside nas conexões pessoais e no engajamento lúdico com o game; e as 'guildas de invasão' (raiding guilds, em inglês), também chamadas de 'super guildas', marcadas por um alto nível de competitividade e um maior comprometimento para perseguir níveis mais avançados do jogo. Ambos os tipos, contudo, acabam misturando ação com trabalho social. Mesmo as raiding guilds mais ambiciosas contam com mecanismos sociais para alcançar o sucesso (Taylor, 2006, p. 43).

Em EvD não há uma diferenciação assim tão clara, mas é possível observar uma maioria de alianças que podem ser consideradas do tipo familiar e uma ou duas, por servidor, que se enquadram no tipo 'super alianças'. São aquelas mais competitivas e poderosas, que sempre ficam em primeiro lugar nos torneios e passam a disputar uma colocação diferenciada não mais no servidor doméstico, mas entre os diversos mundos do game por meio dos torneios entre mundos (crossworlds).

Seja uma aliança familiar ou uma super aliança, defendemos que esses agrupamentos são cruciais para o desenvolvimento de jogadores em qualquer nível, tanto em seu aspecto instrumental quanto social, ao contrário de Taylor (2006, p. 43), para quem as guildas são especialmente importantes para jogadores em estágios mais avançados do game, devido aos benefícios da colaboração. Do lado social, é comum encontrar jogadores refe- 


\section{DISERTACIONES}

ESTUDIOS

Comunicación y dispositivos móviles

ISSN: 1856-9536

Dol de la revista: http://dx.doi.org/10.12804/disertaciones

Volumen 12, Número 1 / Enero-junio 2019

Versión PDF para imprimir desde

http://revistas.urosario.edu.co/index.php/disertaciones

rindo-se à sua aliança como 'família' ou 'casa', como detalharemos mais adiante, e isso "aquece os corações". 0 encontro diário no chat do jogo, as conversas casuais, a cumplicidade, o companheirismo. Do lado instrumental, como já dissemos, participar de uma aliança torna mais fácil ganhar prêmios e ter acesso a recursos e a informações sobre o game. Além do que jogar ao lado de companheiros que estão em níveis distintos acaba sendo um estímulo para que um novato se empenhe mais e assim consiga evoluir mais rapidamente. Na prática, contudo, é raro ver um novato conseguir vaga nas alianças mais poderosas.

O recrutamento de jogadores para uma aliança, aliás, é um processo complexo que envolve diversos fatores e, normalmente, muita discussão entre aqueles com poder de aprovar ou vetar a entrada de novos membros. A força e a experiência do jogador contam muito, mas não bastam. Taylor (2006, p. 42) observa que, no caso das guildas, existem mecanismos de associação que se assemelham aos da máfia, notadamente, reputação, confiança e responsabilidade. Esses mecanismos também percebemos presentes nas alianças de EvD.

A reputação seria o conjunto de habilidades e qualificações do jogador -níveis da conta e dos heróis, equipamentos, quantidade de recursos, comportamento perante o jogo e valores, tais como cumprir acordos e manter uma participação respeitosa nos chats do jogo-. Segundo Taylor (2006, p. 44), "a reputação é considerada por meio da avaliação da habilidade de uma pessoa em representar sua classe, seu comportamento e mesmo seus valores mais amplos (eles colocam as necessidades do grupo acima das suas? São pessoas divertidas?)". É esperado que o candidato se ajuste ao código de conduta existente no grupo. Ao combinar a experiência do jogador, habilidades, comportamento e valores, a reputação tem um sentido muito próximo à ideia de capital social. Esse capital social pessoal é construído ao longo do jogar e torna-se especialmente importante nos níveis mais avançados.

A autora não deixa de lembrar que a aliança também vai construindo sua própria reputação ao longo do tempo, que está acima das reputações individuais. "Em todos os casos enfim o nome da guilda sinaliza uma reputação que está acima e além de qualquer identidade individual de jogador. Ele atua como um significante social e situa o personagem em um sistema maior de reputação, afiliações, favores e mesmo mágoas” (Taylor, 2006, p. 45). Assim, temos guildas/alianças que se tornam famosas, por exemplo, por serem agressivas ou por não respeitarem as regras da brincadeira e essa reputação acompanha cada um dos aliados, especialmente os líderes e o oficialato.

A confiança é outro elemento fundamental porque pessoas que jogam juntas precisam confiar umas nas outras a fim de que aquilo que foi planejado aconteça e, no caso da ocorrência de problemas, o grupo irá se unir para resolvê-los. "A confiança nos companheiros de grupo é um tema comum ao longo do jogo e se torna ainda mais pronunciado no nível mais elevado", diz Taylor (2006, p. 46). De acordo com a autora, o game avançado envolve muita coordenação e cooperação, sendo que a confiança é importante para que os participantes se sintam seguros.

No caso de EvD, confiamos uns nos outros para que as estratégias definidas para cada torneio não 'vazem' para outras alianças, assim como nível de recursos dos jogadores mais tops. Inclusive porque, como aponta Taylor (2006, p. 46), algumas alianças possuem bancos que servem de armazéns para uso coletivo. A preservação das coordenadas desses bancos é algo que requer muita confiança também em EvD. Já o compartilhamento de contas entre amigos ou companheiros de aliança - o que normalmente exige um alto nível de confiança-é uma prática que vem se mostrando problemática. Muitos jogadores de EvD já tiveram suas contas 'zeradas' porque um dia confiaram em alguém, repassaram seu login e senha e acabaram vítimas de atos de vingança ou de puro vandalismo. No entanto, como admite Taylor (2006, p. 47), há situações em que essa prática pode trazer benefícios ao grupo. Como exemplo, podemos citar casos em 


\section{DISERTACIONES}

ESTUDIOS

EvD em que o jogador não pode entrar no jogo em determinado momento e o companheiro entra para coletar prêmios ou para participar de um determinado torneio, coisas que podem fazer diferença no ranking final de uma competição.

Por último, a responsabilidade seria o mecanismo que permeia cada uma das categorias até aqui citadas. Segundo Taylor (2006, pp. 47-48), ela vincula os membros da guilda a tal ponto que, acrescentamos, cada um sintase responsável pelo sucesso ou fracasso do grupo. Portanto, responsabilidade no game é praticamente um sinônimo de participação. Algumas guildas chegam a exigir uma participação consistente, semanal ou diária, e disponibilidade para ajudar o grupo e seus aliados sempre que possível. Quanto maior ou mais poderosa for a guilda/aliança, maior a exigência. Isso, em alguns casos, acaba gerando tensões e conflitos entre os interesses individuais e de grupo. Como explica Taylor,

em guildas mais avançadas há uma relação interessante, e às vezes tensa, entre o indivíduo e o grupo. De um lado, jogadores frequentemente entram nessas guildas por razões pessoais ambiciosas. Eles querem realizar mais com seus personagens e a guilda avançada é a maneira de conseguir isso. Não é incomum ver pessoas deixando suas pequenas guildas familiares para entrar em uma guilda de invasão uma vez que estejam aptas (apesar de frequentemente deixarem um personagem secundário em sua pequena guilda, como forma de manter laços com suas raízes). De outro lado, seus objetivos podem ser alcançados apenas através da ação coletiva massiva (Taylor, 2006, p. 48).

Essa tensão de fato está muito presente, mas não apenas nas alianças dos games digitais. Jogos em equipe, de maneira geral, apresentam esse tipo de conflito em que um membro tenta se destacar mais que o outro ou obter mais vantagens. No caso de $E v D$, há ainda uma particularidade que observamos em relação a uma mudança de comportamento, em alguns casos, no tocante às competições individuais e coletivas. Quando o torneio é apenas coletivo, há baixa adesão, a menos que o jogador enxergue alguma maneira de se beneficiar individualmente, de forma diferenciada em relação aos demais jogadores, então ele se empenha mais. Por outro lado, o quando o torneio é individual e coletivo ao mesmo tempo, costuma haver uma participação mais ampla. Se é apenas individual, a adesão é sempre mais alta. O que não deixa de ser uma idiossincrasia, uma vez que todos, sem exceção, se beneficiam dos resultados dos torneios coletivos e, portanto, alcançar melhores resultados enquanto aliança deveria ser o objetivo comum.

\section{Considerações metodológicas}

Este trabalho foi concebido a partir da experiência das autoras como jogadoras de EvD, uma desde julho de $2014 \mathrm{e}$ outra desde novembro de 2015. Apesar de terem cumprido trajetórias distintas no game, participando de alianças diferentes, no momento em que escrevemos compartilhamos a mesma aliança no servidor EvD70 (antigo Fili70), a Gods of War, e por isso essa aliança foi escolhida como objeto empírico. Quando este trabalho estiver sendo lido, talvez a aliança, o próprio $E v D$ ou quem sabe até o WhatsApp nem exista mais, dada a aceleração característica dos tempos atuais, em especial no que se refere às coisas digitais, todas hiper-reais e vaporosas, como já preconizava Baudrillard (1991).

Inicialmente, o caminho metodológico que trilhamos incluía etnografia com observação participante em duas alianças distintas: a Templários e a Gods of War, ambas do servidor EvD70. Passamos o mês de julho de 2017 observando e participando das conversas que ocorriam nos grupos de WhatsApp dessas duas alianças, procurando

\section{1}




\section{DISERTACIONES}

ESTUDIOS

Comunicación y dispositivos móviles

ISSN: 1856-9536

Dol de la revista: http://dx.doi.org/10.12804/disertaciones

Volumen 12, Número 1 / Enero-junio 2019

Versión PDF para imprimir desde

http://revistas.urosario.edu.co/index.php/disertaciones

identificar os atores que mais interagiam, como interagiam e com quem, quais os principais temas abordados, enfim, todo o fluxo comunicacional. Tiramos fotos das telas (print screen) de várias conversas, a fim de analisar a dinâmica interacional nesses grupos.

Ao longo desse processo, a aliança Templários se dissolveu e passamos a compartilhar a mesma aliança: a Gods of War. Essa mudança brusca nos levou a repensar a metodologia que estava sendo utilizada no estudo, até porque os grupos da Templários no WhatsApp foram imediatamente desfeitos. Como não havia mais a possibilidade de fazer comparações do fluxo comunicacional nos grupos de duas comunidades distintas, optamos por abordar apenas a Gods of War. Ao invés de utilizarmos os dados da observação participante até então coletados, e da forma que foram coletados, decidimos elaborar um relato de experiência, baseado nas memórias de uma das autoras ao ingressar nessa aliança e, posteriormente, nos grupos do WhatsApp.

Partimos, então, para a escrita desse relato. É importante destacar que todos os dados levantados durante a observação participante foram extremamente úteis na elaboração da parte descritiva exposta acima e fundamentais para a construção do próprio relato. Nele, decidimos considerar as impressões iniciais da jogadora enquanto novata no game, a forma como se desenvolvia a interação no aplicativo (no chat da aliança) e como as trocas comunicacionais se modificaram no momento em que houve a sua adesão aos grupos no WhatsApp ("Gods Herói, Kill, Hs...", "Oficiais Base Gods" e "Master Gods"). Ou seja, ao invés de adotarmos a entrevista como um dos instrumentos da etnografia, recorremos à memória e damos voz à própria jogadora, que passa a comandar o desenvolvimento da escrita ao mesmo tempo em que analisa os significados e implicações dessa experiência.

A etnografia digital (também chamada de etnografia virtual, webnografia, ciberantropologia ou netnografia, dependendo do tipo de pesquisa e do autor) vem sendo utilizada em estudos de comunidades e cultura online há algumas décadas (Kozinets, 2012, p. 5). Ao observar o que fazem e o que dizem que fazem os internautas (e nós próprios enquanto internautas também), aproximamo-nos do que faziam os etnógrafos tradicionais que passavam algum tempo observando e participando de comunidades no mundo real. Ao invés de um ambiente natural, temos um ambiente técnico, como destaca Flick (2009, p. 246).

Apperley \& Jayemane (2017) observam que existe uma multiplicidade de abordagens metodológicas quando o assunto são os estudos de games digitais. Para além da ludologia e da narratologia, que os autores chamam de "infame dicotomia", existiriam algumas tendências nessa área que apontam para uma "virada material", atentando para os "contextos, usos e qualidades materiais das tecnologias de jogos, por um lado, e a atenção à análise situada do jogo e dos jogadores, por outro". Essas tendências seriam a etnografia, os estudos de plataforma e o trabalho digital.

No caso da etnografia, que é a abordagem que orienta este trabalho, "os métodos ou abordagens etnográficas fornecem aos estudos de jogo uma maneira de conectar objetos e práticas e de entender essas práticas em relação às vidas e experiências das pessoas que as representam" (Apperley \& Jayemane, 2017, p. 3).

De certo modo, a abordagem que apresentamos aqui se aproxima do que Giddings (2009) chama de microetnografia, isto é, uma análise focada de curto prazo sobre determinado jogo em que a presença (e a experiência imersiva) do pesquisador é tão importante quanto as tecnologias de pesquisa e a rede em estudo. Tais elementos seriam inseparáveis.

Não são poucos os autores que têm utilizado suas próprias experiências de jogo para compor etnografias por exemplo, Pearce (2011), Taylor (2006)-. Até porque boa parte dos estudiosos dessa área -senão todos- são, 


\section{DISERTACIONES}

ESTUDIOS

Comunicación y dispositivos móviles

ISSN: 1856-9536

Dol de la revista: http://dx.doi.org/10.12804/disertaciones

Volumen 12, Número 1 / Enero-junio 2019

Versión PDF para imprimir desde

http://revistas.urosario.edu.co/index.php/disertaciones

antes de tudo, jogadores. $\mathrm{O}$ intuito aqui é mostrar, a partir do relato em primeira pessoa de uma jogadora, como a introdução de um elemento novo -os grupos do WhatsApp- mudou as relações entre os membros de uma comunidade de jogo. Reconhecemos que o estudo é apenas preliminar, mas acreditamos que ele tem potencial para subsidiar e, principalmente, estimular futuras investigações.

\section{Gods of War: impulsionando a comunicação e estreitando laços sociais}

A aliança Gods of War foi criada no servidor EvD70 (antigo Fili70), em outubro de 2014. Em agosto de 2017, a aliança possuía 64 membros, tendo um regente, dois vice-regentes e 12 oficiais. Posiciona-se na segunda colocação do ranking de alianças do servidor (tal posição é definida a partir da soma da força de todos os aliados). Em sua descrição, é dito que "Nossa História Está Em Nós, Onde Estivermos, Haverá Uma Raça Indestrutível e Imbatível ORGULHO DE SER UM GOD OF WAR. Juntos Somos Eternos Gods". O nome da aliança foi inspirado na série de games de ação e aventura God of War (um dos carros-chefes da marca PlayStation), cuja narrativa é, em parte, baseada na mitologia grega.

Entrei na Gods of War em dezembro de 2015. Já havia dois meses que tentava, sem sucesso, evoluir meu status no jogo individualmente. Por conselho de uma jogadora e parceira deste artigo, descartei a possibilidade de seguir sozinha ou iniciar uma nova aliança, visto que esbarraria novamente na dificuldade por falta de aliados, restando-me somente a difícil tarefa de pedir para entrar em alguma aliança já consolidada. Como noob (maneira como chamam os iniciantes no game), também não sabia escolher qual aliança seguir e a descrição de algumas me assustava pela explícita agressividade e competitividade, fazendo-me lembrar que se tratava de um game de guerra. Outra dificuldade era o meu nível no jogo, já que não havia crescido o suficiente para atender às exigências das principais alianças. Assim, consegui entrar na Gods of War por indicação de uma "amiga da minha amiga". A primeira impressão era de que se tratava de aliança na qual as pessoas buscavam apenas se divertir.

Na verdade, a necessidade de interagir era o principal motivo que dificultava minha entrada em The Hobbit - ком alguns meses antes, quando de fato o conheci. Eu não estava muito interessada na possibilidade de novos laços sociais dentro de um game. Entrei na Gods of War decidida a estabelecer o mínimo de comunicação possível e me manter apenas no ambiente do jogo, o que por si só já propiciava um fluxo de interação constante, tanto nos chats (figura 5) quanto no correio. 


\section{DISERTACIONES}

ESTUDIOS

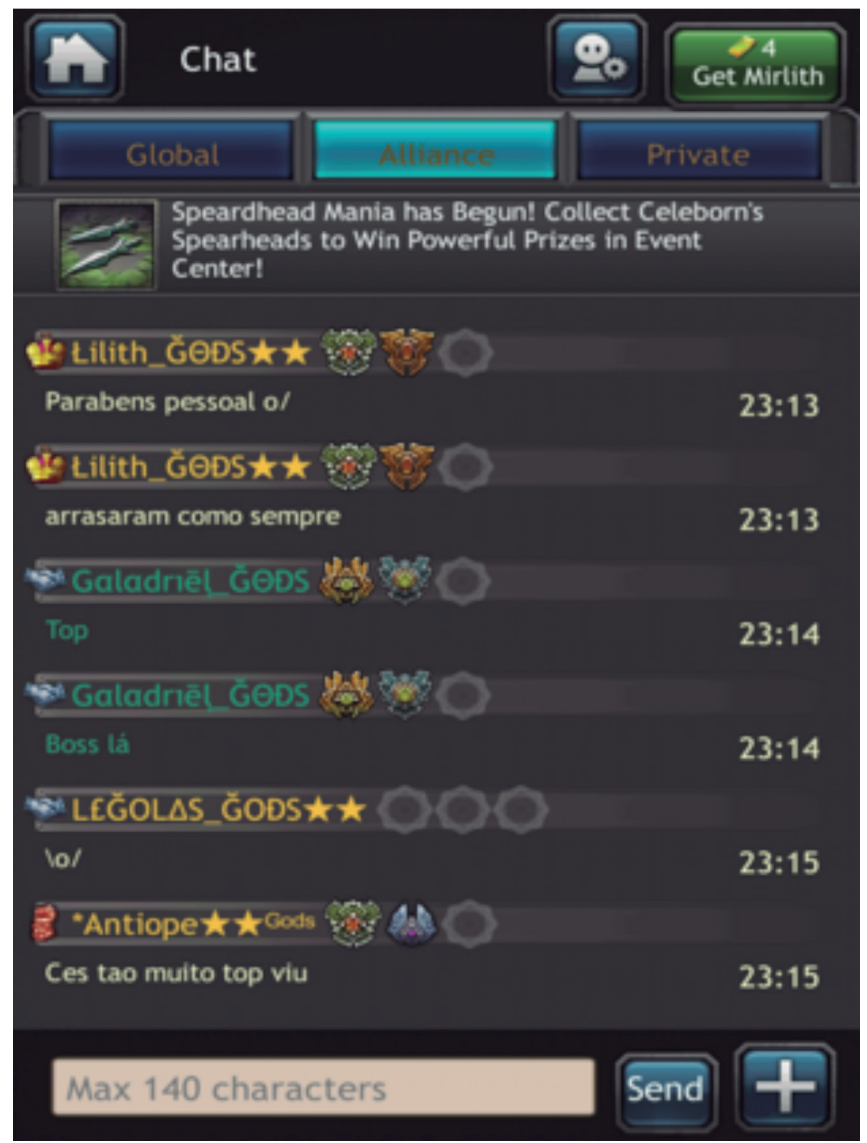

Figura 5. Chat da aliança Gods of War em EvD

Naquele momento havia na Gods muito interesse e disposição dos oficiais e regentes em proporcionar o crescimento dos seus membros e, com isso, da própria aliança. Percebia como um momento expansivo no jogo. A alegação para a quase obrigação de aceitar o convite para os grupos no WhatsApp se assentava na dificuldade de explicar certas questões sem o recurso de imagens e áudios - portanto, uma justificativa pedagógica-. Por todas as dificuldades de evolução que eu já vinha experimentando sozinha e por, a cada dia, perceber mais e mais detaIhes difíceis de compreender, entendi que, se não aceitasse o convite, talvez dois anos depois eu não chegasse a dominar nem metade dos conhecimentos e habilidades que possuo no game atualmente.

Com minha entrada no grupo geral da Gods no WhatsApp, teve início um momento excepcional de descobertas, de crescimento e evolução na minha conta e uma maior aproximação com meus companheiros de aliança. Com o passar do tempo e o crescimento da própria aliança, o número de grupos foi aumentando, chegando ao ponto de, em agosto de 2017, haver cinco grupos permanentes e ativos no WhatsApp, fora os temporários (criados para discutir algum assunto específico, como a fusão de alianças ou cursos para aprender a melhor forma de participar de algum torneio). 
O grupo geral, de nome "Gods of War", é para onde são direcionados todos os aliados. É como se fosse uma área dedicada ao "lazer" e à sociabilidade dos membros, o lugar onde se conversava sobre tudo, de política a futebol, passando pelo dia a dia dos players e suas experiências online e offline, de maneira divertida e descontraída. Outro grupo é o chamado "Gods - Avisos", de caráter mais restrito, apenas para repassar informações sobre novos eventos e orientações da aliança, sem qualquer estímulo a interações, embora seja constante, até hoje, jogadores postarem comentários inoportunos que são imediatamente direcionados pela regência ao grupo geral.

Também existe um grupo para discutir dúvidas diversas, chamado “Gods - Herói, Kill, Hs...”. Nele são postados exemplos, com imagens, dos melhores heróis e equipamentos. Os aliados tiram dúvidas e perguntam sobre formas mais eficientes de obter melhores resultados em cada evento, como pode ser observado na figura 6 . Trata-se de um grupo funcional, embora não seja difícil perceber e participar de conversas triviais sobre os assuntos mais diversos e que não dizem respeito ao jogo.

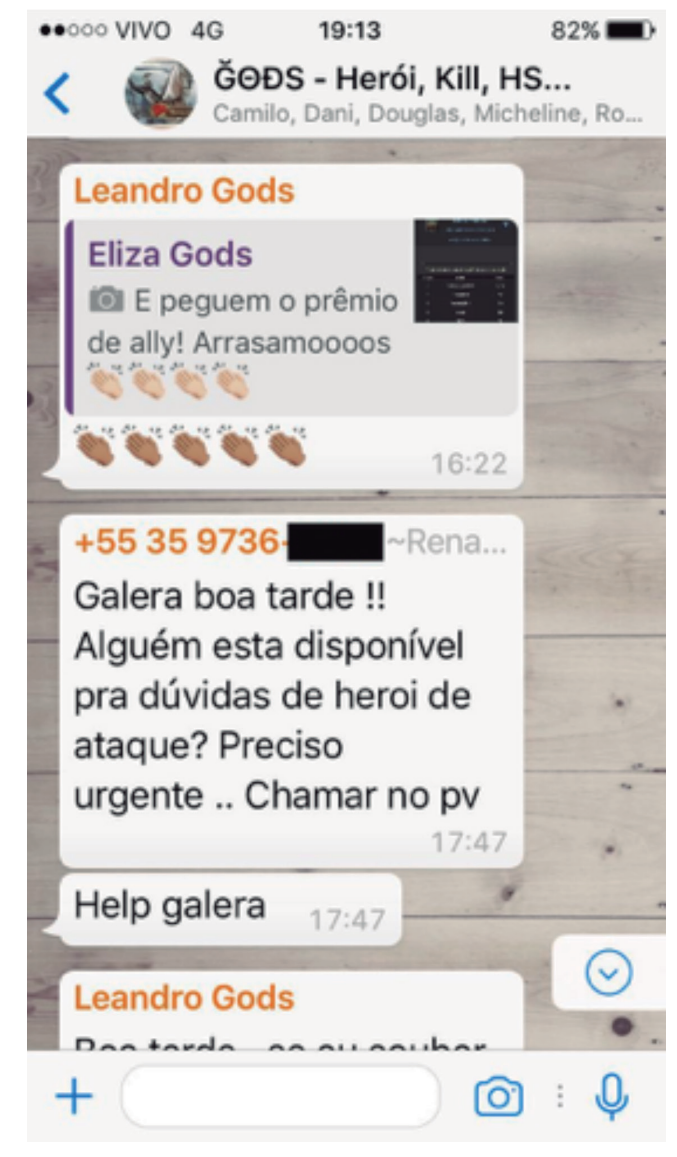

Figura 6. Grupo Herói, Kill, Hs... da aliança Gods of War no WhatsApp

Existe ainda um grupo restrito aos oficiais, chamado "Oficiais Base Gods", destinado aos membros de maior confiança, que geralmente também são os mais ativos no game. Percebe-se claramente uma relação mais afetiva 
entre seus participantes, talvez por ser composto por alguns dos jogadores mais antigos. Ali são discutidas as principais estratégias, orientações da regência e assuntos secretos, que muitas vezes são decididos sem serem levados aos demais aliados, como brigas ou rixas entre jogadores, a decisão de 'kikar' (expulsar) alguém, divisão de tarefas em um torneio etc. Assim como nos demais grupos, não são incomuns assuntos que extrapolam a temática do game, como pode ser observado na figura 7 .

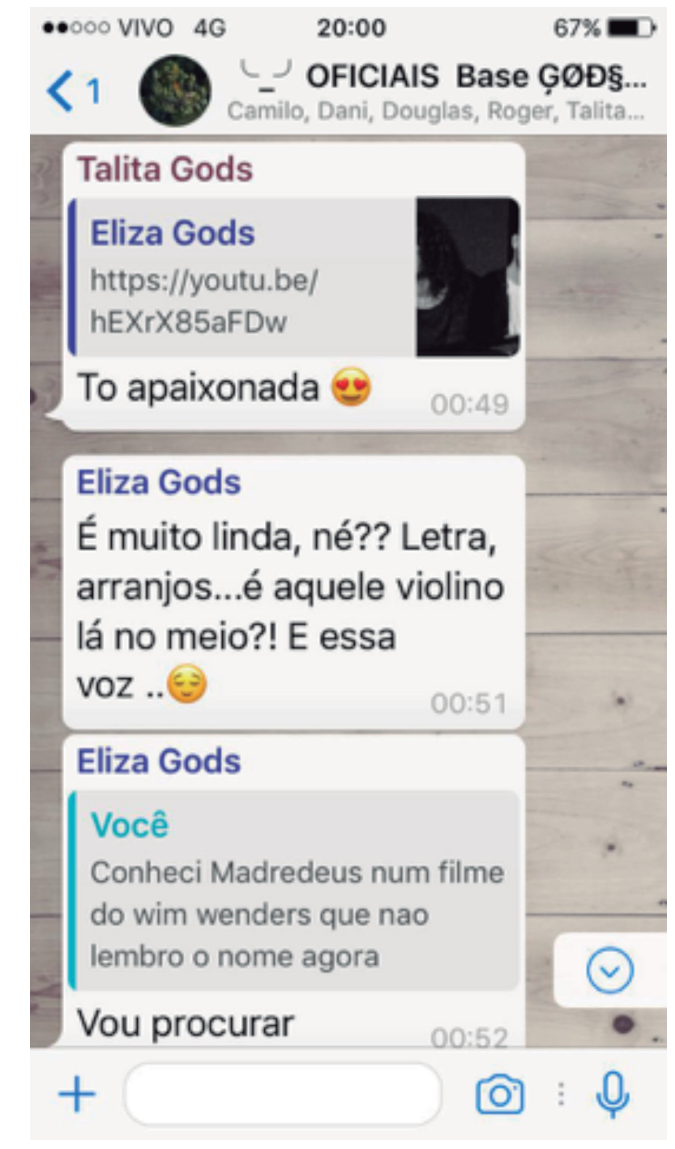

Figura 7. Grupo Oficiais Base Gods da aliança Gods of War no WhatsApp

Existe, por fim, um grupo privativo dos regentes, chamado "Master Gods" (figura 8), onde se tomam todas as principais decisões, para só depois serem passadas aos oficiais e, posteriormente, aos demais jogadores. Este grupo é composto pela regente, os dois vice-regentes, o fundador e primeiro regente da Gods of War e, em alguns momentos, um ou outro membro a ser preparado para ocupar uma das vagas na regência, caso alguém precise se ausentar. É o chamado 'conselho', uma espécie de círculo de confiança. 


\section{DISERTACIONES}

Comunicación y dispositivos móviles

ISSN: 1856-9536

Dol de la revista: $\mathrm{http}: / / \mathrm{dx}$.doi.org/10.12804/disertaciones

Volumen 12, Número 1 / Enero-junio 2019

Versión PDF para imprimir desde

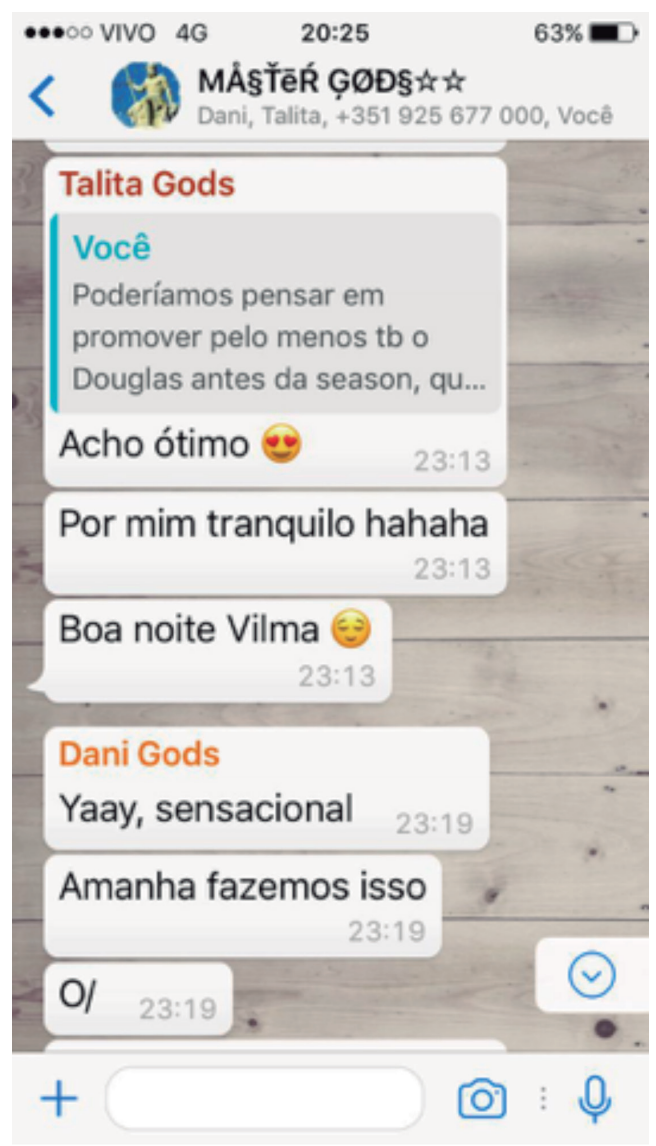

Figura 8. Grupo Master Gods da aliança Gods of War no WhatsApp

Pela intensidade das informações trocadas via WhatsApp, percebia-se de imediato a complexidade e riqueza de detalhes que este game de estratégia oferece. Tive a oportunidade de participar de um curso sobre o torneio Campaign High Score (CHS) para aprender a usar a calculadora que mencionamos anteriormente, a evolução dos heróis, melhoramento dos equipamentos, cidades e outros artifícios que influenciavam diretamente nos resultados desse evento. Cada etapa do curso foi ministrada por um colega com mais habilidade técnica no tema em questão. Algo fascinante que estimulava a participação nos torneios, fazendo com que as disputas envolvessem não só recursos, mas sobretudo habilidade, estratégias e inteligência.

A participação nesse curso foi determinante para eu perceber a complexidade do evento e até hoje considerar o cHs como o melhor torneio, o que me estimulou ainda mais a tentar aperfeiçoar meu desenvolvimento. Esse contato através do WhatsApp aumentou a minha vontade de jogar na medida em que percebia nos aliados o mesmo interesse de crescer e dominar as diversas possibilidades oferecidas.

A princípio entrei apenas no grupo geral, mas devido ainda à minha resistência a uma interação extrajogo, logo me aborreci com o volume surpreendente de mensagens diárias, que muitas vezes expressavam opiniões divergentes das minhas em relação a assuntos que realmente não me interessavam discutir com pessoas 'estranhas' e que 


\section{DISERTACIONES}

ESTUDIOS

Comunicación y dispositivos móviles

ISSN: 1856-9536

Dol de la revista: http://dx.doi.org/10.12804/disertaciones

Volumen 12, Número 1 / Enero-junio 2019

Versión PDF para imprimir desde

http://revistas.urosario.edu.co/index.php/disertaciones

possivelmente me fariam desistir do game ou sair da aliança, como, por exemplo, comentários preconceituosos sobre assuntos como política ou piadas sexistas.

Por curiosidade, no início, criei o hábito de ler ou tentar ler as mensagens diariamente. Já que minha participação era insignificante, como noob não me sentia à vontade para iniciar ou participar das conversas, mesmo que fossem relacionadas ao jogo. Tentava tirar minhas dúvidas apenas lendo os comentários, passando dias sem fazer nenhuma intervenção. Não era fácil conseguir acompanhar as conversas em tempo real, que aconteciam em vários horários do dia e da noite. Essa leitura demandava tempo, o que diminuía minha disponibilidade para jogar. Meu celular também não suportou o volume de mensagens do grupo geral, além do fato de me desconcentrar no trabalho, por toda hora perceber novas mensagens chegando. Então pedi para sair desse grupo e migrei para os de avisos e de dúvidas.

Neste momento inicial, a heterogeneidade das mensagens e de opiniões que circulavam no grupo geral não funcionou, para mim, como um atrativo nem como um estímulo para o game. Pelo contrário, reforçou minha ideia inicial de seguir isolada e me fazia questionar se eu realmente estava no espaço certo, ao passo que, quando as conversas se direcionavam para as questões de The Hobbit - Kom/EvD, o envolvimento, a dedicação e a seriedade dessas mesmas pessoas me impressionavam e me faziam querer ir mais adiante. $O$ fato de ver jogadores de diferentes idades, cidades, profissões, tão interessados em um jogo aliviava um pouco a sensação de culpa difundida na ideia do senso comum de jogos como 'perda de tempo'.

Com minha evolução, fui promovida ao cargo de oficial e na sequência fui adicionada ao grupo "Oficiais Base Gods". Quando entrei, existiam 16 participantes. Alguns permanecem até hoje, embora não joguem mais. Outros já não participam tanto, mas se apresentam sempre que a aliança necessita de uma ajuda extra. Eles se mantêm nesse espaço de sociabilidade pela amizade gerada durante os anos de participação no game. Isso é explicitamente estimulado pela regência como forma de manter os laços. Como diz o próprio lema da aliança, "juntos somos eternos Gods".

Talvez pelo meu perfil como player mais discreta, pela segurança de ter evoluído mais no jogo, e estando em um grupo mais seleto, aos poucos fui me sentindo mais à vontade para participar das discussões, fora a necessidade de cumprir o compromisso implícito atribuído à minha função de oficial, de me posicionar em certos assuntos demandados pela regência. A essa altura eu já me sentia 'em casa' e, estimulada pelas mudanças ocorridas no próprio game, fui participando cada vez mais de conversas que muitas vezes estavam longe de ter EvD como tema.

Nesse grupo, é comum haver longas conversas permeadas por muitos emojis, indicações de músicas, bandas, filmes e séries televisivas (a figura 7, por exemplo, apresenta um diálogo que surge quando um dos membros posta o link para um videoclipe), assim como no grupo geral, do qual me desfiliei antes. Qualquer tema que despertasse o interesse de dois ou mais participantes podia se estender. Exemplos de assuntos que sempre renderam muita conversa são a série de Tv Game of Thrones e indicações de músicas e filmes, além de bate-papos triviais sobre nossas atividades etílicas nos finais de semana ou, simplesmente, brincadeiras divertidas com o auxílio de memes, fotos, vídeos e áudios feitos pelos próprios aliados ou disponíveis na internet.

Com minha total participação no grupo dos oficiais, fui falando cada vez menos no chat da aliança dentro de EvD, mesmo no espaço reservado aos oficiais. Se antes eu preferia usar o tempo que dispunha só para jogar e estar no game, agora era como se eu nutrisse minha vontade de jogar nesses grupos do WhatsApp e entrasse no jogo especificamente para executar tarefas, salvo algumas exceções e momentos de conversas com algum outro 


\section{DISERTACIONES}

ESTUDIOS

jogador que preferia, assim como eu no início, não participar dos grupos nas redes sociais. Pode-se dizer que, na medida em que minha participação aumentou nos grupos da aliança no WhatsApp, diminuiu minha interação nas chats rooms de EvD e observei que essa mudança também ocorreu com meus companheiros.

Por fim, fui adicionada para participar, como uma espécie de 'estagiária', do grupo dos regentes da Gods, com a função de ajudar, aprender e substituir algum membro, caso houvesse necessidade. Ao final deste artigo, fui novamente promovida, desta vez ao cargo de vice-regente, o que mais uma vez estimulou minha permanência nos grupos do WhatsApp e deu um novo fôlego ao game.

\section{Considerações finais}

O relato preliminar que apresentamos nos traz algumas questões importantes para pensarmos como as comunidades de jogo são lugares de cultura e sociabilidade: i) os jogadores crescem e evoluem mais rapidamente quando participam de uma aliança/guilda; ii) as alianças/guildas possuem, além do aspecto instrumental, uma dimensão social de pertencimento e compromisso mútuo; iii) os espaços de sociabilização oferecidos dentro do game são insuficientes para as necessidades comunicacionais dos jogadores, por isso eles recorrem a grupos de aplicativos como o WhatsApp; e iv) os grupos da aplicativos como o WhatsApp trazem elementos extrajogo, próprios do cotidiano dos jogadores, que também são importantes para a sociabilização.

Nos grupos das comunidades de jogo criados no WhatsApp, observamos uma intensificação do compartilhamento de informações sobre o game (como montar os melhores heróis, obter as maiores pontuações nos torneios etc.) e de interações que nem sempre têm o jogo como referência. O game é o foco, mas a partir dele surgem outros elementos relacionados a temas diversos, já que os grupos funcionam como uma extensão permanente do jogo, 24 horas por dia, inclusive porque as alianças contam com membros que estão sob os fusos horários mais distintos. É o game sempre à mão, sem necessariamente estar dentro do jogo, mesmo que o player esteja no seu ambiente de trabalho ou estudo, ou ainda em outras situações sociais, como reuniões offline de amigos ou familiares.

Em termos interacionais, é como se toda a comunicação entre os aliados tivesse migrado do jogo para um aplicativo de mensagens instantâneas, o que, de alguma maneira, não deixa de esvaziar as trocas comunicacionais dentro do game. 0 "círculo mágico" do jogo, de que nos fala Huizinga (2007), é então estendido para as atividades cotidianas dos participantes, aumentando a complexidade da função social do jogo de intersubjetividade e interação referida por Pearce (2011). Os grupos do WhatsApp potencializam a sociabilidade proporcionada pelo jogo e reforçam o desenvolvimento de redes e habilidades sociais, característico das player communities, mas que vão além do próprio jogo, problematizando a ideia de Caillois (1990) de que a contaminação do game com a vida cotidiana dos jogadores levaria ao fim do próprio jogo.

Em nosso relato é possível perceber os mecanismos de associação que Taylor (2006) observa nas guildas, exclusivamente no ambiente do game, transpostos para grupos de um aplicativo de mensagens instantâneas. As guildas ou alianças, assim como a máfia, possuem uma estrutura do tipo familiar baseada na reputação, na confiança e na responsabilidade. A Gods of War se encaixa na descrição de guilda do tipo familiar e não uma 'super guilda', o que deve ter facilitado o ingresso da jogadora novata, aceita por indicação e não por reputação, ainda que, provavelmente, o histórico dela tenha sido analisado por GPS. Ao longo do tempo, a jogadora foi demonstrando cada vez mais

\section{9}




\section{DISERTACIONES}

ESTUDIOS

Comunicación y dispositivos móviles

ISSN: 1856-9536

Dol de la revista: http://dx.doi.org/10.12804/disertaciones

Volumen 12, Número 1 / Enero-junio 2019

Versión PDF para imprimir desde

http://revistas.urosario.edu.co/index.php/disertaciones

responsabilidade e acabou ganhando a confiança da regência, ao ponto de galgar posições - oficial, conselheira e, por fim, vice-regente-.

Diante de tudo isso, podemos dizer, ainda que preliminarmente (devido à abordagem adotada, baseada em memórias), que a crescente utilização de grupos do WhatsApp para conectar membros de uma aliança de um game como o EvD nos parece ser uma das evidências de como a comunidade de jogo pode sobreviver para além do jogo. Não apenas isso. Ela pode sobreviver ao fim do próprio game, como testemunhou Pearce (2011) no caso do Uru. Da mesma forma, os companheiros da Gods of War também acreditam que a aliança sobreviverá a despeito do jogo chegar ao seu fim, pois "juntos serão eternos Gods".

\section{Referências}

1. Aarseth, E. (2001). Computer game studies, year one. Game Studies, 1(1). Recuperado de http://www. gamestudies.org/0101/editorial.html

2. Apperley, T., \& Jayemane, D. (2017). A virada material dos game studies. Lumina, 11(1). Recuperado de https://lumina.ufj.emnuvens.com.br/lumina/article/view/721/498

3. Batista, M. D. G. (2010). Second life: corpo e identidade no mundo virtual (Dissertação de Mestrado, Universidade Federal de Pernambuco, Recife). Recuperada de http://www.repositorio.ufpe.br/bitstream/handle/123456789/9490/arquivo436_1.pdf?sequence=1\&isAllowed=y

4. Baudrillard, J. (1991). Simulacros e simulação. Lisboa: Relógio D’Água.

5. Caillois, R. (1990). Os jogos e os homens. Lisboa: Edições Cotovia.

6. Entertainment Software Association (ESA). (2017). Essential facts about the computer and video game industry. Recuperado de http://www.theesa.com/wp-content/uploads/2017/04/EF2017_FinalDigital.pdf

7. Flick, U. (2009). Pesquisa qualitativa online: a utilização da internet. In U. Flick, Uma introdução à pesquisa qualitativa (pp. 239-253). Porto Alegre: Artmed.

8. Gaea. (2017). Gaea acquires Kabam's classic mobile games and publishing business. Recuperado de http:// www.gaea.com/en/newsdetail?newsid=54

9. Giddings, S. (2009). Events and collusions: a glossary for the microethnography of videogame play. Games and Cultures: A Journal of Interactive Media, 4(2), 144-157. Recuperado de http://eprints.uwe.ac.uk/8359/1/ Events_and_Collusions.pdf

10. Huizinga, J. (2007). Homo ludens: o jogo como elemento da cultura. São Paulo: Perspectiva.

11. Juul, J. (2011). Half real: video games between real rules and fictional worlds. Cambridge, MA: MIT Press.

12. Kozinets, R. V. (2012). Netnography: doing ethnographic research online. Los Angeles-London-New DelhiSingapore-Washington: SAGE.

13. Pearce, C. (2011). Communities of play: emergent cultures in multiplayer games and virtual worlds. Cambridge, мA: мiт Press.

14. Sensor Tower. (2017). The Hobbit - Kingdoms of Middle-earth. Recuperado de https://sensortower.com/ ios/us/gaea-mobile-ltd/app/the-hobbit-kingdoms-of-middle-earth/558823262/

15. Sioux, Blend New Research, ESPM. (2017). Pesquisa game Brasil 2017. Recuperado de https://docs.wixstatic. com/ugd/29fc6b_bcd70218d1e94cd1ac6dc714e7f8f443.pdf 


\section{DISERTACIONES}

\section{ESTUDIOS}

16. Taylor, T. L. (2006). Play between worlds: exploring online game culture. Cambridge, MA: MIт Press.

17. Tönnies, F. (2001). Community and civil society. Cambridge: Cambridge University Press.

18. vol Cinema. (2017). Bilheteria do cinema mundial bate recorde de arrecadação em 2016. Recuperado de https://cinema.uol.com.br/noticias/efe/2017/03/23/bilheteria-do-cinema-mundial-bate-recorde-de-arrecadacao-em-2016.htm

19. Warner Bros. (2012). The Hobbit - Kingdoms of Middle-earth. Recuperado de https://www.warnerbros. co.uk/games/the-hobbit-kingdoms-of-middle-earth 